\title{
The theoretical basis of the CGIL's analysis of the Italian economic decline
}

\author{
Guglielmo Forges Davanzati* \\ Nicolò Giangrande ${ }^{\#}$
}

\begin{abstract}
This paper deals with the Italian economic decline from a double perspective. First, it provides a reconstruction of the main Post Keynesian arguments explaining the bad macroeconomic performance of the Italian economy, starting from the end of the "economic miracle". Second, it proposes a re-reading of the CGIL's view, showing that is it consistent with a theoretical approach based on the fundamental assumptions and policy prescriptions of the Post Keynesian framework.
\end{abstract}

Keywords: Italian economic decline; Labour market; Unions.

JEL Classification: E6; J5.

\footnotetext{
"University of Salento, Department of History, Society and Human Studies. University of Cambridge, Department of Land Economy. Email: guglielmo.forges@unisalento.it

\# University of Salento, Department of History, Society and Human Studies. Email: nicolo.giangrande@unisalento.it
} 


\section{Introduction}

In the last decades of the XX century, there have been deep economic and social changes, which have hit the most globalised economies, including Italy. In Europe, the so-called European Social Model (ESM) was beat hardly by globalisation. Indeed, neoliberal policies - characterized by budgetary rigour, maintained stable prices to generate competitiveness in international markets, the dismantling of the welfare state, privatisation of public services and the flexibilisation of labour market - put under pressure the trade unions and led to different results in the European Union (EU) countries, as shown by Bernaciak, Gumbell-McCormic and Hyman (2015).

In fact, the impact of the crisis has increased inequality between countries especially within the Euro Area (EA) countries - and within themselves as well. Italy, such as other southern European countries, had implemented strong public spending cuts and broad labour market flexibilisation.

This period has been characterized by weak economic performance, with a slow - or negative - GDP growth. The manufacturing industry declined and public services were privatised, both sectors where unions had a strong affiliation. These changes have contributed to the unemployment growth and of the non-standard and precarious forms of employment.

We should take into account that Italy has been promoting a gradual flexibility in labour relations and the reduction in social protection since the 1980s. The first measures in the 1980s were introduced into legislation through negotiations among social actors. Later, in the 90s this flexibility was seen as necessary to respond to the demands of the productive systems, which started to face the global markets. In the 2000s, the flexibility was introduced in a massive way through new legislation that considered it to be essential for technical, productive and organisational reasons. This has changed the labour market configuration: increase of non-standard contractual forms, occupational discontinuity and continuous mobility from a job to another. This led to a new kind of uncertainty, which had deepened the social and territorial inequalities and produced new forms of market segmentation (Altieri, 2009). The evolution of flexibilisation, however, was not followed by a strong structural reform of the social protection system, which traditionally protected the adult worker with a fulltime and permanent contract in the larger industries, and which excludes atypical and fixed-term workers (Leonardi, 2009). 
In Italy, the union density is $37 \%$ (2013 data) and collective bargaining coverage is $85 \%$ (2010 data). In the Italian system, the employment regulation depends more heavily on legislation than collective bargaining, which makes unions more interested in influencing government policies rather than negotiating with employers' organisations (Bernaciak et al., 2015)

The Italian General Confederation of Labour (hereafter referred as "CGIL", according to its initials in Italian) is the largest Italian trade union confederation in terms of trade union membership. In fact, in comparison to the other two Italian trade union confederations - the Italian Confederation of Workers' Trade Unions (CISL) and the Italian Union of Labour (UIL) - historically the CGIL has always had more affiliates. According to the union data, in 2016 the CGIL had 5.4 million members, the CISL 4 million and the UIL 2.2 million.

This division into three trade union confederations is the result of the Cold War. Indeed, in 1944, with the so-called "Pact of Rome", the three main trade union streams - Communist, Socialist and Christian Democrat - founded the CGIL, a single and unitary trade union confederation. Later, in 1948 and 1950 there were divisions that led to the creation of the CISL, formed by the Christian trade unionists, and the UIL, made by the republicans and social-democrats, while in the CGIL a communist, a socialist and a leftist area were structured.

There have been several attempts to rebuild a unitary confederation, but with no success. Among them it is important to mention the "CGIL-CISL-UIL Federation", the joint organisation between the three confederations which operated from 1972 to 1984 (Pepe et al, 2003). Actually, it was in 1973 that the CGIL decide to enter in the European Trade Union Confederation (ETUC).

It is worth showing that CGIL had an emphasis on "labour", while the CISL emphasised "unions". The CGIL has a well-established horizontal structure in the territory (Camere del Lavoro), while the CISL has a vertical structure divided by categories (Federazioni), which gives priority to action in the workplace. In addition, in matters such as democracy within the unions and the decentralisation of collective bargaining, the two confederations have divergent positions (Baccaro et al., 2011). Accornero (1992) identifies the CGIL with the defence of workers' rights, the CISL with the search for social solidarity, and the UIL with the representation of workers as citizens.

Later, from 1992-93 Italy implemented the labour rights cuts and the dismantling of the Welfare State. The period from that moment to the present day 
has been characterised by neoliberal and conservative policies, among this there was also the so-called "rigour" in the management of public spending. During the four cabinets led by Berlusconi, there was also the refusal of social dialogue with unions - mainly with the CGIL - and, finally, the attempt to weaken and divide the trade union movement.

On the other hand, the 2006 elections that led to the Second Prodi's cabinet (2006-08), generated a strong expectation in the CGIL. This was mainly due to the government being closer to the unions, as well as there being individuals from the union movement in the parliament. This led the CGIL to becoming closer to the government, which allowed a dialogue on issues and thus reduced the already low conflict.

The 2008 international crisis worsened the national context and brought about new difficulties, which the CGIL had already denounced in 2002 during the general strike ("against the decline of the country"). Since 2003 and throughout this period, CGIL has always shown a proactive stance to demand changes in economic and social policies, as well as working to expand social alliances in the country, involving young people, students, the unemployed, etc.

Between 2004-2013, the CGIL has recorded, despite the economic crisis, an increase of its affiliates, reaching 5.6 million. During this period, the CGIL also found a way to merge various union federations, from the 30 in the 1970s (Bernaciak et al., 2015), until the 19 in 1985 (Baccaro and Pulignano, 2015) and, finally, to 12 Federations.

This paper aims to help to understand how the CGIL has interpreted the causes and effects of the economic decline, which factors were most responsible for its rise and what were the main proposals suggested by this trade union confederation.

It has contributed significantly to the analysis of the Italian economy, and its policy prescriptions have been widely debated in Italian academia and, of course, in the political arena. Quite surprisingly, very little attention has been devoted to this issue and, more specifically, to the CGIL's analysis of the so-called Italian economic decline.

This paper deals with the Italian economic decline from a double perspective. First, it provides a reconstruction of the main Post Keynesian arguments explaining the bad macroeconomic performance of the Italian economy, starting from the end of the "economic miracle". Second, it proposes a re-reading 
of the CGIL's view, showing that is it consistent with a theoretical approach based on the fundamental assumptions and policy prescriptions of the Post Keynesian stream.

In particular, it will be stressed that:

1. the CGIL assumes that the Italian economic crisis, in the form of increasing unemployment, was (and is) due to a lack of aggregate demand, consequent to the reduction of social spending;

2. the reduction of the rate of growth of labour productivity and of aggregate demand is conceived as a consequence of the massive reduction of public investment;

3. policies of labour market flexibility are presumed to reduce domestic demand and, at the same time, to negatively affect the path of labour productivity.

The period under consideration is 2003-2013. The rationale for this choice is the following. On 18th October 2002 the CGIL organised a general strike against the Berlusconi government, in order to attract attention to the need to make radical changes in economic and social policies. This can be considered the starting point of our study to understand how the CGIL interpreted the causes and effects of the Italian economic decline and to identify the main union proposals to deal with it. Most of the proposals made in this decade (2003-2013) were merged in 2013 in the Program for Jobs, that is an overall economic plan set by the CGIL for the recovery of the Italian economy.

This paper is organised as follows. Section 2 proposes an interpretation of the causes of the Italian crisis. Section 3 discusses the CGIL's analysis of this problem and the policy prescriptions. Particular attention will be devoted to the Italian labour market through the data provided by ISTAT and the unemployment trend. The study the CGIL's analysis and proposals on how to deal with the Italian economic decline will rely on Rassegna Sindacale (weekly union publications), and the Piano del Lavoro (hereafter referred as "Program for Jobs") launched in 2013. Section 4 concludes.

\section{The Italian economic decline}

After the so-called Italian economic miracle of the 1960s, mainly driven by exports, the 1970s marked a significant reduction of the rate of growth of the Italian economy. Most historians and economists imputed this to the marked increase in workers' bargaining power, not only in the labour market but also in the political 
arena (cf. Bellofiore, 2011). The extraordinary increase in the price of oil also helped to generate strong inflationary pressures. The combination of wage increases and imported inflation made it even more difficult for the Italian firms to continue exporting via price competition. The mechanism at the basis of the high rates of growth of the 1960s was interrupted. In the 1970s both the social conflict and the wage share were particularly high. As regards to the first issue, one can consider the path of the Italian union density rate, as described in Figure 1.

Figure 1. Union Density Rate in Italy (1960-2013)

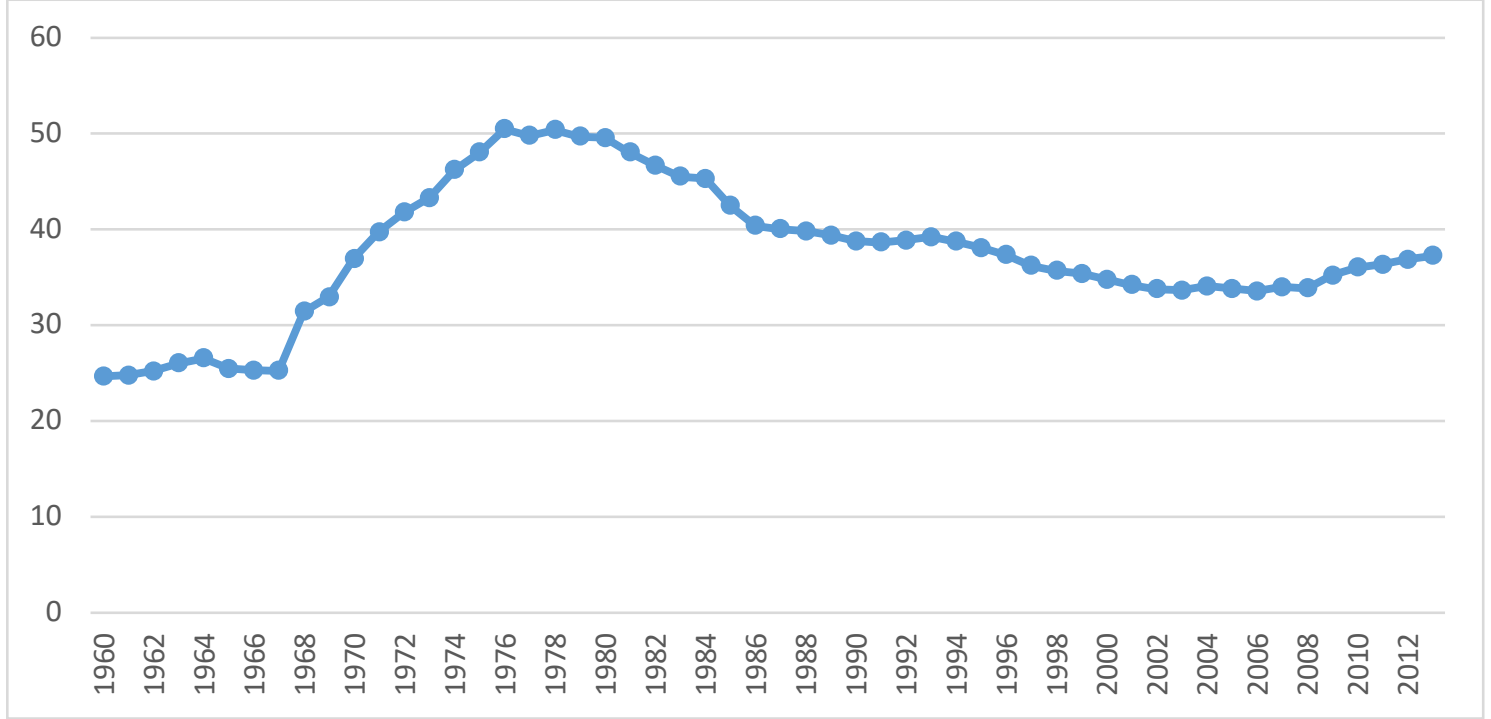

Source: our elaboration on Visser database (2015).

Figure 2 shows the path of the wage share in Italy from 1970 to 1980. It is significant that, after the peak of union density in 1976, the wage share began to fall, with a significant acceleration in the ensuing decades.

Figure 2. Labour share in Italy (1970-1980)

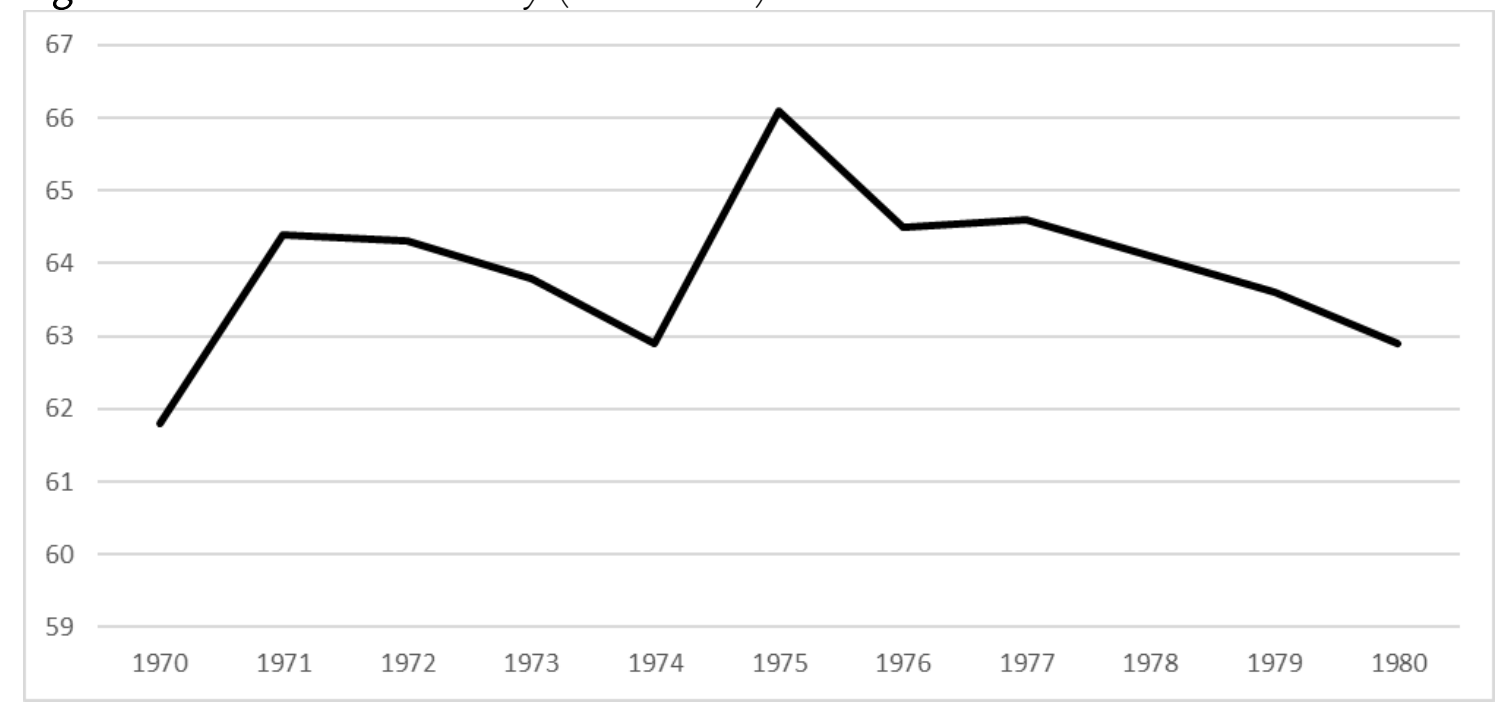

Source: ILO (2018). 
Figure 3 shows the dynamics of investment (both private and public) in Italy during the 1970-1980 period. In general terms investments were $25 \%$ of GDP on average. The highest investments were recorded in 1974 (26.8\% of GDP) - above all in their public components - while the lowest were registered in $1978(23.85 \%$ of GDP).

Figure 3. The dynamics of investments in Italy: (1970-1980)

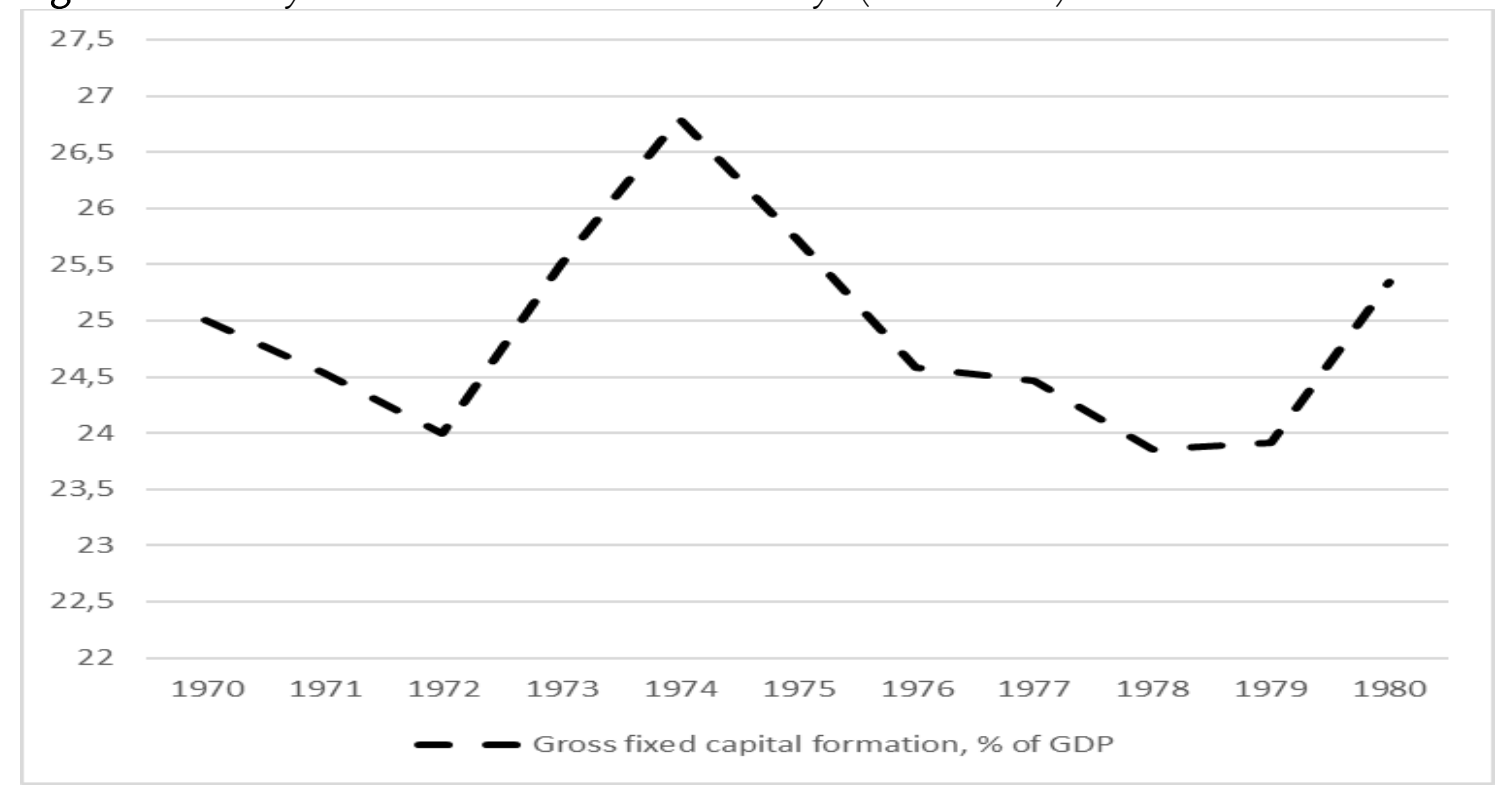

Source: OECD (2015)

Notice also that during the 1975-1978 period, investments and the wage share both dropped. This can be imputed to the fall of the growth rate and to the increase in the inflation rate following the rise in the price of oil. Accordingly, Italian stagflation dates back to the mid-1970s.

Italian firms reacted to the increased wage share and the workers' growing political power in two ways. First, they decentralized production in order to prevent social conflict (Graziani, 2000; Moro, 2015). This gave rise to the birth of small firms, which, starting from that period, was the main specificity of Italian capitalism: i.e. the small average size of firms ('nanismo imprenditoriale' or 'entrepreneurial dwarfism'). Second, big Italian companies began trying to increase their profit margins, which had been reduced by the wage rises of the previous decade, via speculative activities (Bellofiore 2001, Graziani 2000). In this respect, as Arrighi (2007) pointed out, financialisation is a response to the decline of industrial profits.

The combination of these dynamics generates two outcomes: the decline of private investment as a result of the increasing financial accumulation and the decline of private consumption due to the reduction of the wage share, with the 
consequent reduction of internal demand ${ }^{1}$. In a long-run dynamic, Italy followed a recessive path which is particularly evident in the current crisis (Forges Davanzati and Giangrande, 2019).

Importantly, the decline of effective demand and the consequent rise of unemployment weakened workers' bargaining power in the political arena, allowing the Government to implement 'pro-firm' economic policies: i.e. tax cuts on profits, restrictive fiscal policies and precarious employment. These measures mainly matched the interests of big companies. In fact, for big firms, it is not profitable for the Government to expand domestic demand, particularly if it is designed to improve workers' conditions (Kalecki 1943). Big firms can obtain profits by selling abroad and/or by means of increasing monopolization ${ }^{2}$. By contrast, small firms which produce for the domestic market are interested in keeping net public expenditure high. The resulting scenario of intercapitalist conflicts is at the basis of political choices relating to public expenditure and the tax system.

Evidence also shows that among advanced economies, Italy has undoubtedly been one of the worst performers in the last two decades. In particular, starting from the 1990s, Italy has been experiencing a constant decline of aggregate demand and a continuous drop in labour productivity (Lampa and Perri, 2014). The fall of aggregate demand is to be imputed to the reduction of private consumption deriving from the reduction of the wage share, the reduction of private investment connected with the increasing financial accumulation of the Italian firms and the austerity measures implemented starting from the early 1990s (in particular, with the restrictive fiscal policies of 1992 and 1993). The restrictive fiscal policies were officially implemented to reduce public debt and reduce aggregate demand, and they evidently failed to reach this goal, insofar as Italian public debt constantly increased in relation to GDP, and it is still increasing. The reduction of labour productivity, in turn, mainly depends on the slowdown of capital accumulation, with reference to the dynamics of both private and public investment. OECD (2018) reports that the growth rate of labour productivity in Italy in the period $2001-2010$ is about $0 \%$, while, on average, EU27 countries

\footnotetext{
${ }^{1}$ Most studies show - both on the theoretical and empirical ground - that rentiers' propensity to consume is low, implying that the wealth effect can be considered negligible (cf., among others, Hein and Van Treeck, 2010).

${ }^{2}$ This latter effect is made possible by the falling profits of small firms (and even their bankruptcy) owing to the reduction of public spending, and the consequent increase in the market shares of big firms and/or the processes of mergers and acquisitions.
} 
experienced a growth rate of about $2 \%$ in the same period. Importantly, policies of labour market deregulation, introduced by what is called the Treu Act in 1997 (and subsequently by the Biagi Act in 2003), contributed to the acceleration of this dynamics, negatively affecting wages and private consumption. OECD (2015) reports that, in Italy, the Employment protection legislation index fell from 3.57 at the beginning of the mid-1990s to about 1.5 in 2014 and that the labour share significantly declined in that period. Labour market deregulation contributed to the reduction of the growth rate for two main reasons. First, it discouraged innovation, insofar as firms can stay competitive by cutting wages following the decline of workers' bargaining power (Pini, 2013). Second, labour flexibility negatively affects aggregate demand via the reduction of the propensity to consume. The rationale for this is based on the assumptions that i) workers aim at maintaining their consumption constant over time; ii) flexible labour contract are expected to increase workers' effort (the so-called discipline effect); iii) flexible labour contracts increase workers' uncertainty ${ }^{3}$. On these bases, a lack of composition effect occurs. On the microeconomic level, the individual firm finds it profitable to hire with flexible labour contracts, insofar as, due to the 'discipline effect', it expects that workers will increase their effort, with the consequent increase in labour productivity and profits. By contrast, on the macroeconomic level flexible labour contracts, insofar as they increase workers' uncertainty, push workers to increase their precautionary savings (cf. Pacella, 2009). Furthermore, labour precariousness produces a vicious circle at the expense of workers: since the unemployment rate tends to rise, this reduces workers' bargaining power both in the labour market and in the political arena, allowing the Government to implement further measures of labour market deregulation ${ }^{4}$.

\footnotetext{
${ }^{3}$ As Ramskogler (2007) point out i) in a capitalist economy, uncertainty is not evenly distributed among social classes and ii) workers, in particular, suffer from higher levels of uncertainty, due to job insecurity.

${ }^{4}$ This argument is consistent with Kalecki's view that unemployment is a discipline device that capitalists use in order to impede workers (and unions) from controlling economic policy. As Kalecki (1943, p.326) wrote: "... under the pressure of the masses the maintenance of full employment would cause social and political changes which would give a new impetus to the opposition of the business leaders. Indeed, under a regime of permanent full employment, " the sack " would cease to play its role as a disciplinary measure. The social position of the boss would be undermined and the self assurance and class consciousness of the working class would grow. Strikes for wage increases and improvements in conditions of work would create political tension, It is true that profits would be higher under a regime of full employment than they are on the average under laisser- faire ; and even the rise in wage rates resulting from the stronger bargaining power of the workers is less likely to reduce profits than to increase prices, and thus affects adversely only the rentier interests. But 'discipline in the factories' and 'political stability' are more appreciated by the business leaders than
} 
Relying on the presumed idea that "small is beautiful", during the 1980s, Italy did not implement industrial policies, reducing public spending with the aim of reducing public debt and systematic deficits in the balance of trade (Graziani, 2000).

The outcome of these decisions has been twofold, and counterproductive for economic growth. First, cutting public spending (and raising tax) has not been a successful strategy in reducing the ratio of public debt/GDP, which has kept growing. Secondly, the drop in internal demand has reduced firms' profits, leading to further shrinkage in their average size and to a drop of investment. This, in turn, has been followed by increased unemployment - especially among the young and among highly educated individuals ${ }^{5}$ - reduction of profit margins and/or bankruptcies, lower investments and consequently a lower rate of growth in labour productivity. Moreover, the decline of aggregate demand reduced firms' solvency and, as a result, made it less profitable for the banking sector to accommodate firms' demand for credit (Forges Davanzati, 2016). This effect has been particularly intense for small firms (and for firms located in Southern Italy), which operate in domestic market. By contrast, big companies involved in speculative activities benefited from the reduction of internal demand in Italy, insofar as low demand presupposes low public spending, which, in turn, presuppose a low supply of State bonds in the financial markets, allowing them to sell their bonds more easily (Forges Davanzati, Pacella, Salento 2019). Moreover, as Graziani (2003, p.137) stresses: "for finance to increase its weight as compared to production ... [it is necessary] that agents in debt towards banks be prepared to obtain loans from agents endowed with liquidity holdings, thus replacing bank debt by debt towards other agents". In the theoretical context of the monetary theory of production, where Graziani elaborated this view, "this can easily happen whenever a credit squeeze occurs and firms have financial problems, and unable to get the required

profits. Their class instinct tells them that lasting full employment is unsound from their point of view and that unemployment is an integral part of the 'normal' capitalist system". While Kalecki referred to the possibility, on the part of capitalists, to fully manage economic policy by disciplining workers with unemployment, an extension of this argument is proposed here: i.e. capitalists - via their influence on policy-makers - can use labour precariousness to generate further labour precariousness. For a reconstruction of the recent debate on the effects of labour flexibility on the path of employment in Italy, cf, among others, Forges Davanzati and Giangrande (2017).

${ }^{5}$ Cingano et al. (2010) report that Italian firms react to the decrease of demand by limiting firing and not hiring. This may depend on two phenomena: first, labour hoarding, normally in the cases of innovative firms; second, disguised unemployment for firms (extremely numerous in Italy, particularly in the South) which employ relatives, involving a psychological cost in firing. 
credit from a bank, try to take advantage of liquidity holding existing in the nonbanking sector" ${ }^{\prime \prime}$.

Finally, it is also worth noting that Italy is also the country in the Eurozone which experiences the highest increase in taxation on labour?

Figure 4 shows the long-run path of labour share in the three important countries of the European Monetary Union (Italy, Germany and France). As observed in most OECD countries, labour share is significantly lower than in the 1970s, particularly in Italy. Computing adjusted labour shares allows us to tackle the measurement issues in the labour share. Therefore, by considering the simple labour share we would have a bigger difference between Italy on one hand and France and Germany, on the other hand. Two main differences between Italy and France-Germany are to be considered. First, Italy experienced a more intense cycle of class struggle during the 1970s and the subsequent policies of wage moderation were more intense than in the other countries. Second, this difference also reflects the higher proportion of self-employed in Italy ${ }^{8}$. The increase of union density in Italy during the 1970s both reflected a profound political transformation of the Italian institutions, with workers gaining increased political power with respect to the previous age of wage moderation, and produced a stop in the macroeconomic mechanism at the basis of the so-called economic miracle.

It is worth noting that the decline of wages did not significantly affect net exports. On this issue regarding the Italian debate, the dominant view supports the idea that wage moderation should lead to decreasing costs, reducing prices and increase of exports. This view is based on the assumption that Italian exports are driven by price-competitiveness.

\footnotetext{
${ }^{6}$ In a Marxist theoretical framework, Fine (2013) finds a relation between recession and financialization in these terms. As demand decreases, this involves the increase in the firms' demand for credit from the banking sector, because "meeting payments becomes vital for survival" (p.53), with the consequent increase in interest rates and "interest bearing capital". Accordingly, the processes of financialization should become more and more intense in recessive phases.

${ }^{7}$ This also reflects the decline of workers' bargaining power in the political arena and, at the same time, can be considered the outcome of more intense austerity policies (compared to the other European countries) that the Italian governments implemented starting from the beginning of the 1990s, with a significant acceleration in 2011-2012.

${ }^{8}$ A similar point was raised by Gollin (2002).
} 
Figure 4. Adjusted labour shares in France, Germany and Italy over the period 19642016

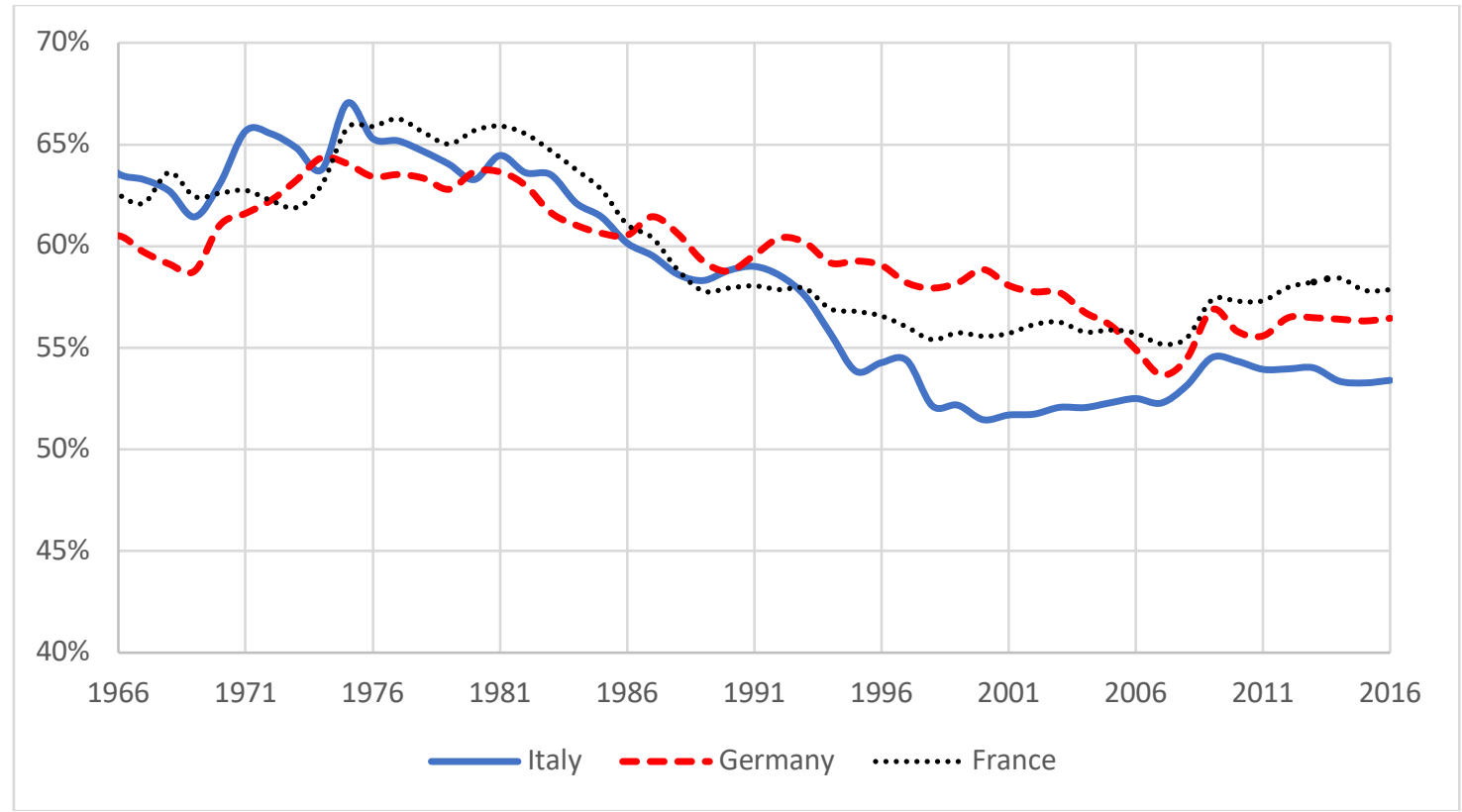

Source: authors' computation based on AMECO (2018).

On the economic policy plane, a reduction of net public spending should allow firms to increase their export via wage moderation and, hence, price competitiveness (cf. Blanchard and Giavazzi, 2003). At the same time, the decline of internal demand consequent to the reduction of public spending should reduce import via the reduction of private consumption. However, for Italy both these effects do not appear to work fully, for two main reasons. First, Italian exports are mainly driven by non-price competitiveness: goods produced in the agribusiness sector are exported mainly via their quality; luxury goods are exported under the operation of the "Veblen effect", also labelled "Made in Italy" effect ${ }^{9}$. Evidence suggests that both price and income elasticity of Italian exports are relatively low (cf. Felettigh and Federico, 2011). Second, imports did not significantly decrease insofar as the reduction of wages modified the structure of consumption in the direction of increasing subsistence consumption. Moreover, due to the relative stability of consumption, imports were not significantly affected by the decrease of wages, and most subsistence goods were not produced by Italian firms. The collapse of Italian exports in the period under consideration - with particular reference - to the period starting from 2008-2009 appears to confirm the view that austerity policies combined with labour market deregulation did not generate an export-growth path. Further considerations are in order. First, the decline of exports

\footnotetext{
${ }^{9}$ The so-called Veblen effect stablishes that as the unitary price increases so does demand, which particularly applies to luxury goods.
} 
can be also imputed to the increase of uncertainty. Second, the increase of protectionist measures on a global scale, starting from 2008-2009, has negatively affected Italian exports (Ferrari, 2016) ${ }^{10}$. Given that wage moderation aims to increase exports, it is interesting to see that this did not occur. ISTAT (2015) certifies that the improvement of the Italian balance of trade is almost entirely due to the decline of import. On a more general point, ISTAT (2015) also finds that the Italian firms are less present in international trade in comparison with other European firms.

\section{The CGIL's interpretation}

The CGIL, the largest Italian trade union organisation, called for a general strike in 2002 to draw attention to Italy's so-called economic decline. We can say that the CGIL has actively participated in the wider discussion mentioned above on the economic decline that started in 2003. Although there were previous union actions, the general strike called by the CGIL on 18th October 2002 to draw the Berlusconi Government's attention to the need to make radical changes in economic and social policies (Epifani, 2002). This can be considered the starting point of our study to understand how the CGIL interpreted the causes and the effects of the Italian economic decline and what were the main union proposals to deal with it. The following sections will deal with i] a preliminary analysis of the Italian labour market (motivated by the CGIL's obvious interest in the labour dynamics); ii] the CGIL's interpretation of the Italian economic decline and its policy prescriptions.

\subsection{The Italian labour market}

Since in the CGIL's analysis the labour market has a great importance - along with economic policies, of course - this section provides a description of the path of employment, unemployment and inactivity. In this way, it is possible to understand the prior labour market conditions and the subsequent CGIL proposals designed to deal with the unemployment drama (Giangrande, 2016). All the following charts have been elaborated starting from the data extracted from the

\footnotetext{
${ }^{10} \mathrm{~A}$ further consideration is in order. Most of the export-oriented Italian firms are located in Northern Italy. As Graziani (2000) remarked, this involves that policies devoted to stimulate exports (for instance, devaluations of the Lira in the 1980s and 1990s) had perverse redistributive effects at the expense of the less developed regions. One can consider that the idea that exports are mainly driven by non-price competitiveness is one of the most important contribution of Kaldor to the theory of international trade (cf. Kaldor, 1989) consistently with the theoretical framework approached here.
} 
ISTAT data warehouse in May 2017.In Italy, from 2003 to 2013 the number of people employed (aged 15+) fell by 54 thousand units. This is the result of a drastic drop in the male component (-611 thousand units) and an increase in the female component (+558 thousand units). After the global crisis that hit Italy in 2008, people employed shifted from 23 million to almost 22.1 million. This drastic reduction (-900 thousand) was mostly caused by the male component. Since 2008, employment has fallen in the whole country, but with different territorial intensity: while in the Mezzogiorno it has fallen by -531 thousand units, in the Northern it has dropped by -331 thousand, and in the Central it has only decreased -38 thousand.

Figure 5 . Employed $(15+)$ by gender $(2003=100)$

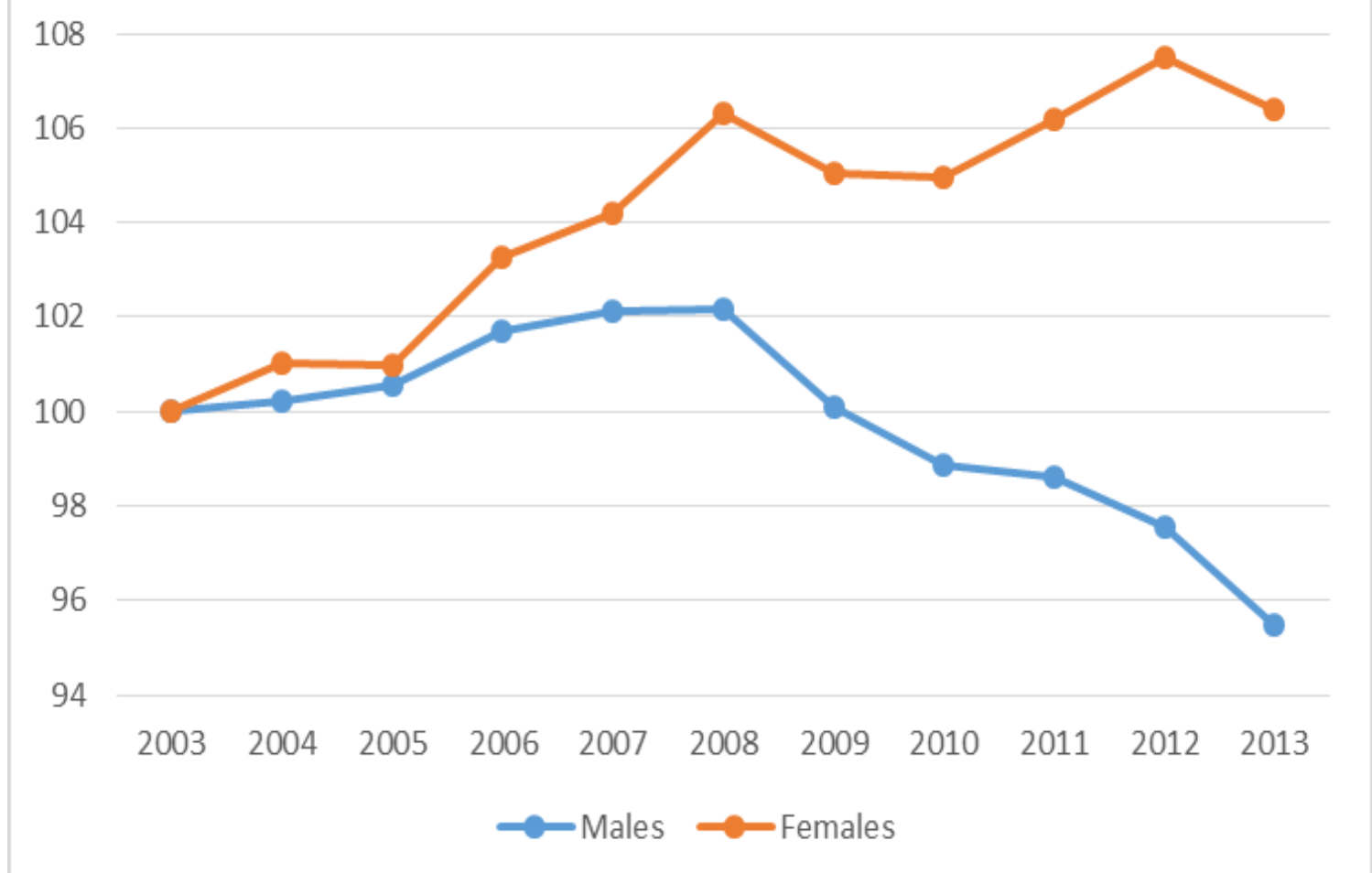

Source: our elaboration from ISTAT (2018) 
Figure 6 . Employed $(15+)$ by macro regions $(2003=100)$

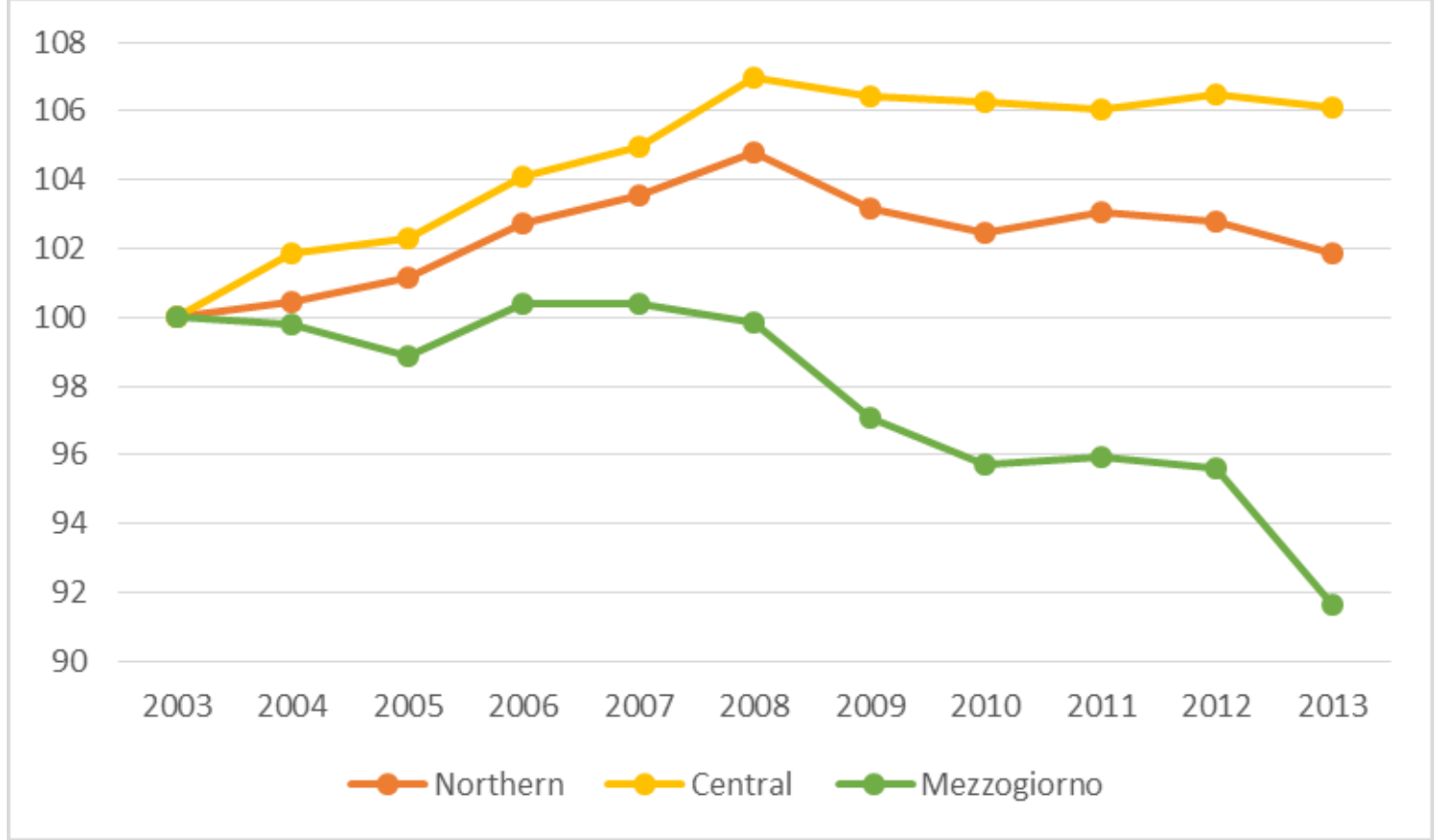

Source: our elaboration from ISTAT (2018)

In 2003, the total stock of unemployed people aged $15+$ ( 2 million) was concentrated mainly in the Mezzogiorno (60\%). In the Northern and Central areas, instead, the unemployed corresponded to $24 \%$ and $16 \%$, respectively.

From 2008, the unemployment was on the rise: shifting from 1.6 million in 2008 to just over 3 million in 2013. The increase of +1.4 million, most of them concentrated in the North of Italy (41\%) and in the Mezzogiorno (41\%), and the rest in the Center (18\%). This increase was composed of more men $(62 \%)$ than women (38\%).

In 2013, approximately half of all the unemployed in the country were in the Mezzogiorno (more than 1.4 million). The remainder was mostly concentrated in the North (1 million) with the Central Italy having the smallest concentration (564 thousand units).

In 2003, inactive people (aged 15-64) represented a pool of 14.1 million people. From 2003 to 2007 , it increased by +319 thousand units, in which the male component grew more (+168 thousand units) than the female one (+151 thousand units). 
Figure 7. Unemployed $(15+)$ by gender $(2003=100)$

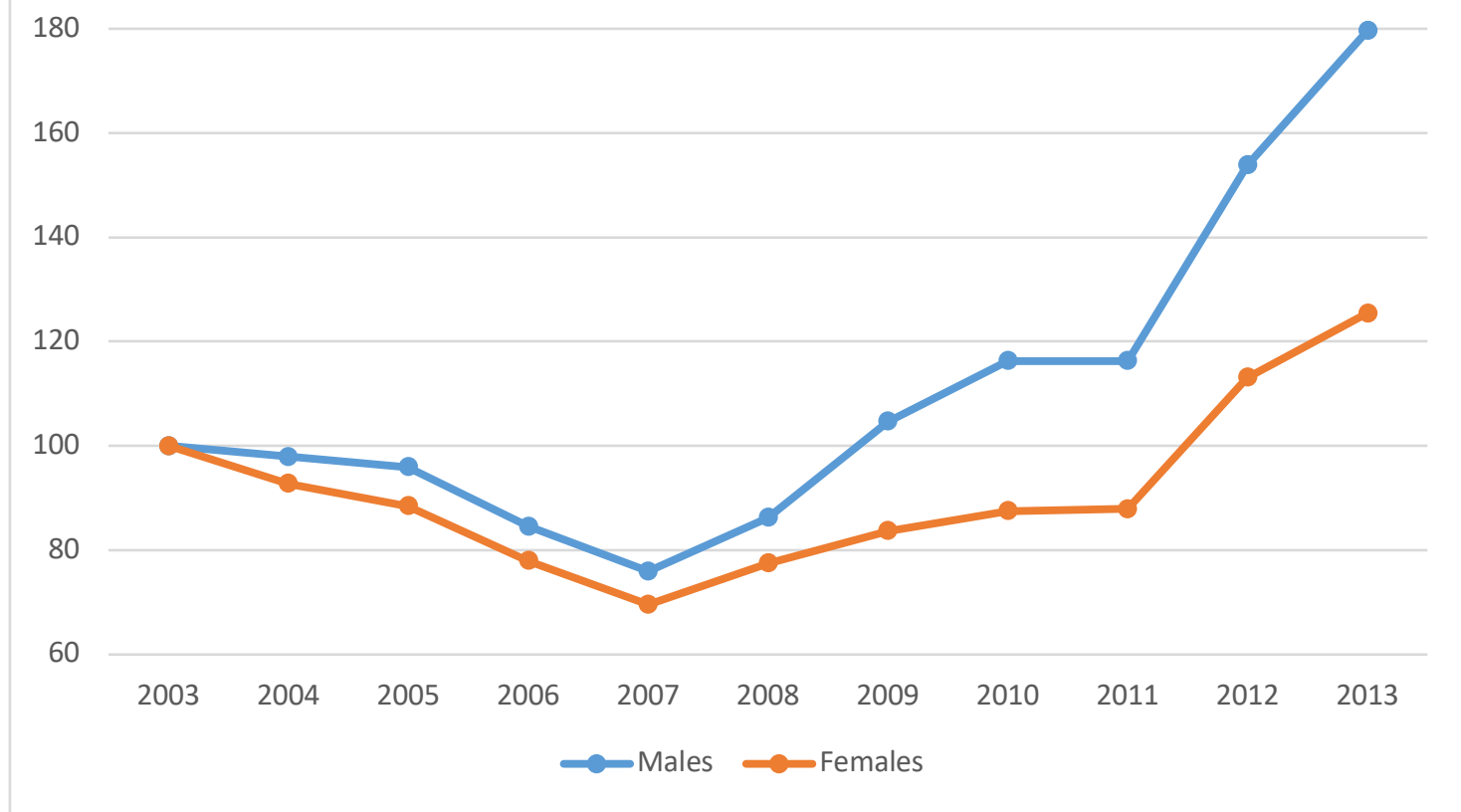

Source: our elaboration from ISTAT (2018).

Figure 8. Unemployed $(15+)$ by macro regions $(2003=100)$

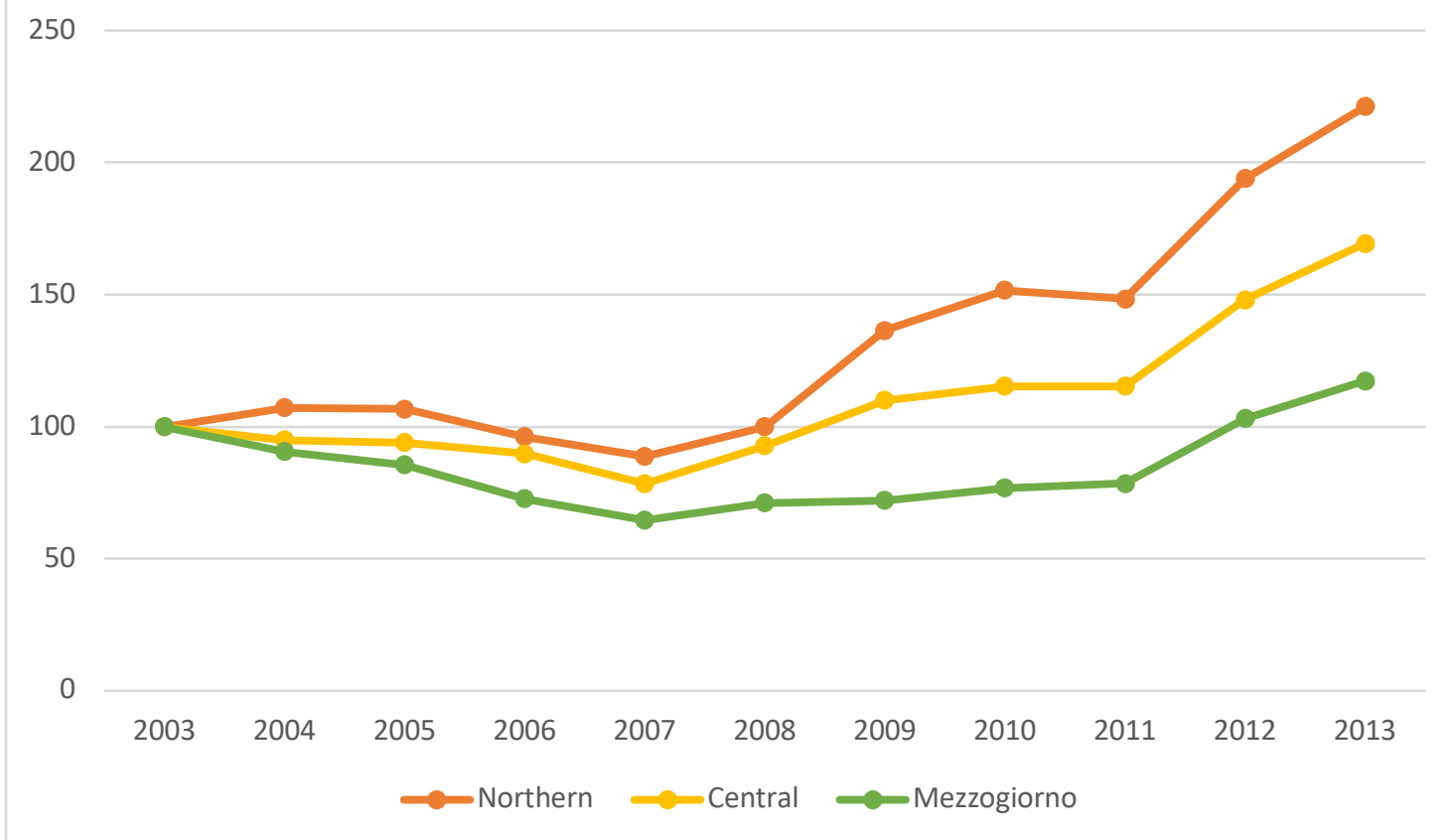

Source: our elaboration from ISTAT (2018).

In 2013, after the crisis started in 2008, inactive people fell to -1 thousand units, because the greater participation of men (+252 thousand units) was counterbalanced by almost the same reduction of women's numbers (-253 thousand units). 
The number of inactive people was already growing from 2003 to 2007 especially in the Mezzogiorno (+463 thousand), while they had decreased in the North of Italy (-134 thousand units) and in the Central Italy ( -10 thousand units).

During the crisis, however, the growth of inactive numbers ( +1 thousand) was mainly due to the Central ( +26 thousand) and Mezzogiorno ( +4 thousand) while they decreased in the Northern (-31 thousand units).

Figure 9. Inactive $(15-64)$ by gender $(2003=100)$

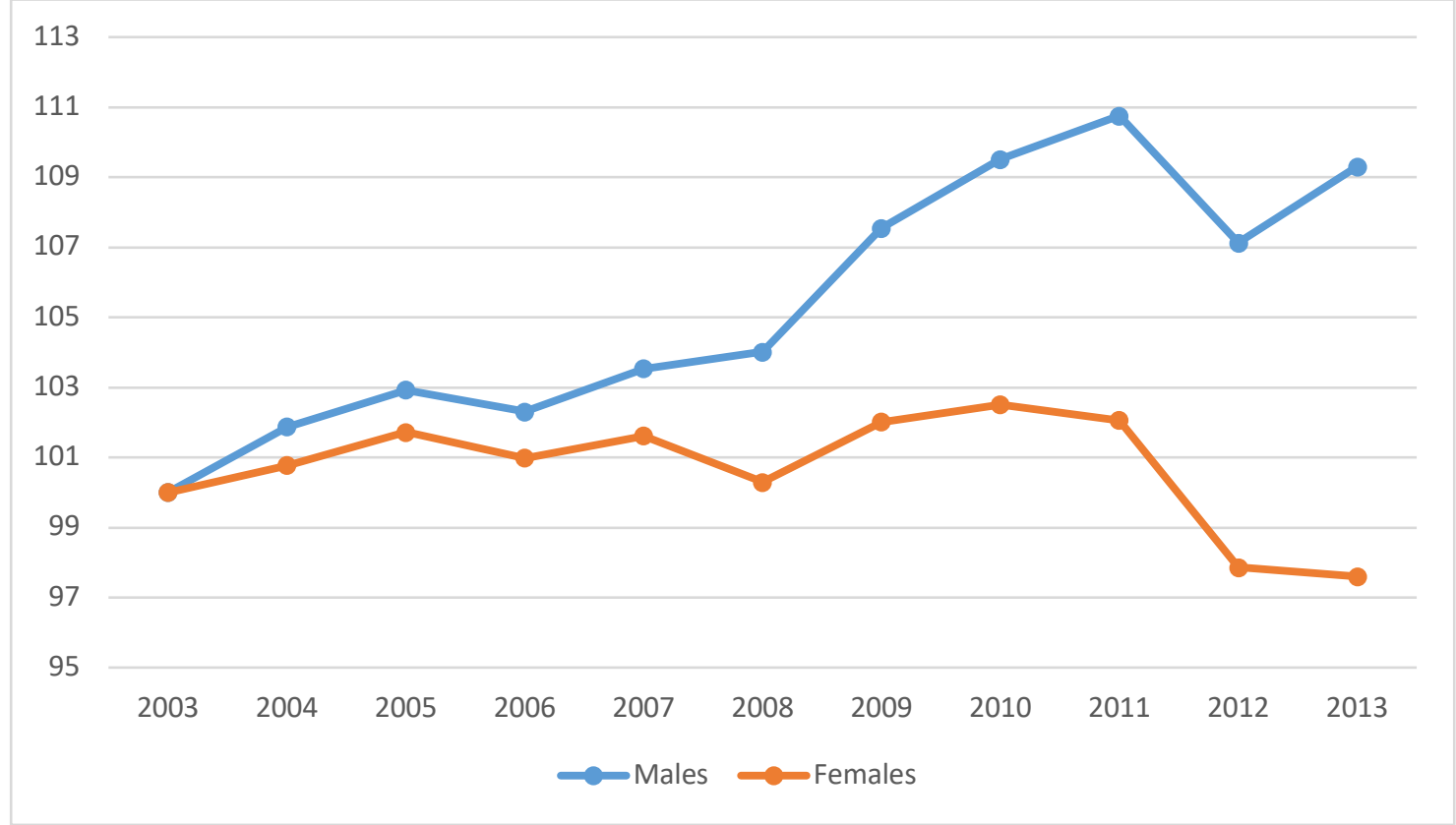

Source: our elaboration from ISTAT (2018).

Figure 10. Inactive (15-64) by macro regions $(2003=100)$

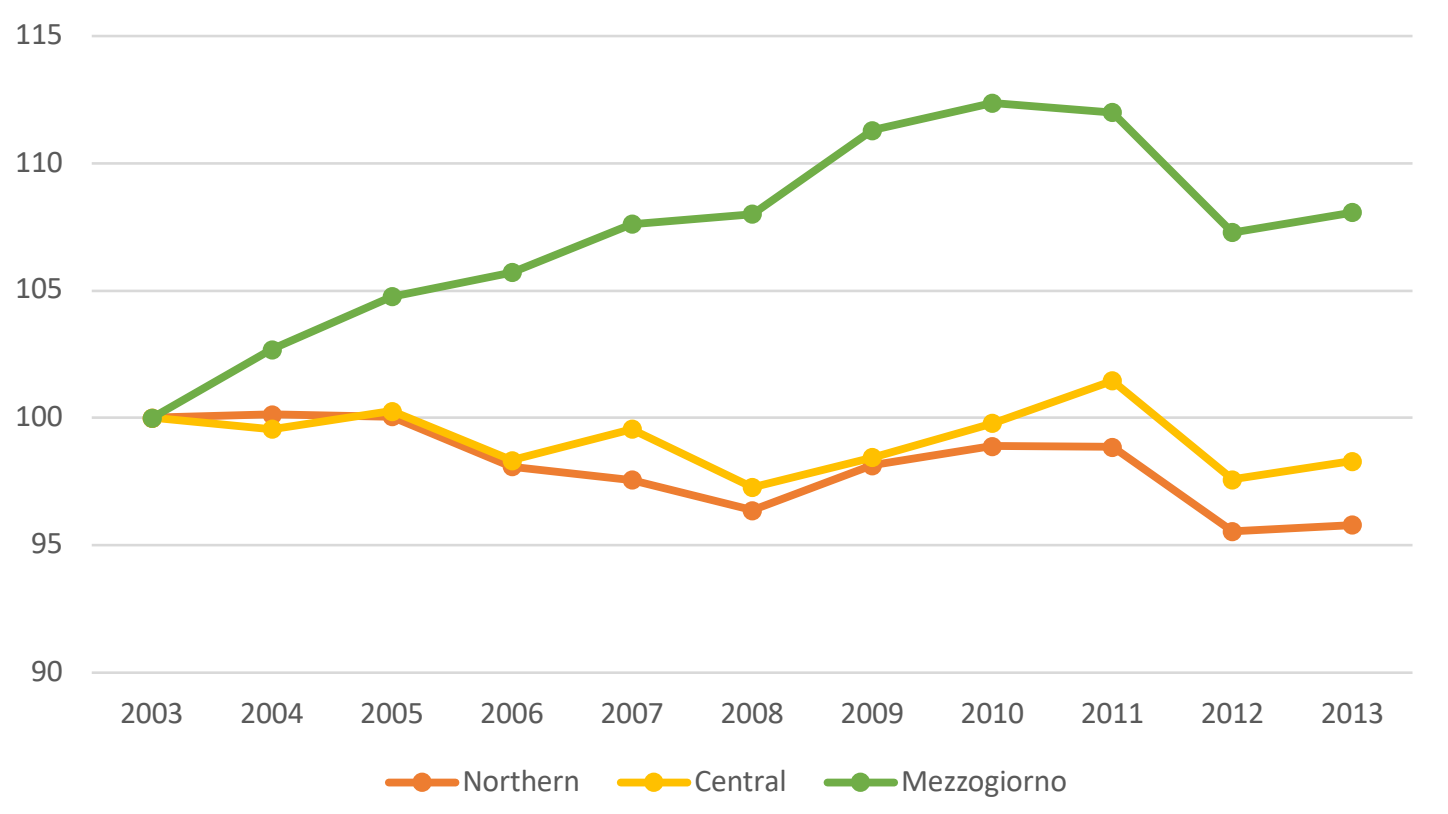

Source: our elaboration from ISTAT (2018). 
It is interesting to see that in the 2003-2007 period the decline of unemployment in the Mezzogiorno (-437 thousand units) was not due to an increase in the number of employees (which, in fact, grew by just +26 thousand units), but mostly to an increase in the number of the inactive (+463 thousand units). In addition, in the successive period (2008-2013), the drop in the number of employees (-531 thousand units) in the Mezzogiorno corresponded to an increase in the unemployed ( +570 thousand units) and inactive ( +4 thousand units).

Anyway, the most alarming data comes from the growth of the long-term unemployed, a group made up of those who have been looking for jobs for more than 12 months. This phenomenon is worrisome because there is a hysteresis effect and, therefore, a loss of skills (Layard et al., 2005). Indeed, in 2003, the long-term unemployed were $49.42 \%$ of all the unemployed people in Italy, while in 2013 it reached $56.36 \%$. In 2011, the number of long-term unemployed exceeded those of short-term duration. In the following years (2012-2013) this number was consolidated while, in 2013, short-term unemployment showed moderate growth. In Italy, long-term unemployment tended to react later even in the presence of improved labour market conditions (Reyneri, 1995), which means it would be difficult to reabsorb the whole pool.

The crisis hit the most vulnerable social groups such as temporary and precarious workers, young people and women, above all in the more fragile geographical areas where the social safety net was made up of their families. It had a negative effect on employment and intensified inactivity while unemployment was limited thanks to the Cassa Integrazione Guadagni (Altieri, 2010), that is the redundancy payment. Moreover, all this accentuated the traditional dualism of the Italian economy (Dota, 2010) and instability and insecurity became characteristics of the Italian labour market.

Unemployment has changed its composition and its dynamics give us a picture of one of the structural problems of the Italian economy. However, it cannot explain the entire labour market trend, indeed it is necessary to further examine the classes of inactive people called the "grey zone" (ISTAT, 2011) - which means "available but not seeking" and "seeking but not available" - and also all the segments that represent people on the dividing line between the state of worker and non-worker.

Carra (2010) believes inactive people constitute a part of the unemployment figure. For this reason, he believes that the traditional criteria for measuring 
unemployment is not adequate to represent the real situation and he proposed the adoption of new parameters (Carra, 2012).

In 2012, the CGIL's Institute of Social and Economic Research (hereafter IRES-CGIL) elaborated another index called 'Occupational Sufferance Area' (Area Sofferenza Occupazionale) which takes into account the unemployed, discouraged people available to work, and workers that receive redundancy payment as explained by Ferrucci (2012). Later, the IRES-CGIL provided another index 'Occupational Distress Area' (Area Disagio Occupazionale), which includes people who have a temporary job because they could not find a permanent one, and those who have a part-time job because they could not find a full-time one (Ferrucci, 2013).

Thus, the CGIL tried to represent the occupational problems clearly, providing an assessment of the number of under 65-year-olds who are obliged to stay out of the labour market or those that have a different job from the one they wish for. This attempt deserves attention because it tries to outline a weighting situation that was not indicated by the official statistics.

\subsection{Low quality development and the need for a structural change}

The starting point of the CGIL's analysis is a critique to the economic policy of Berlusconi's Government. Indeed, at the beginning of the 2000s the second Berlusconi Cabinet (2001-2005) promoted some structural reforms with the purpose of boosting growth, with the strong backing of the CONFINDUSTRIA, the largest Italian industrial employers' confederation led by then-president Antonio D'Amato (2000-2004). This development model was essentially based on: a) less fiscal pressure along with tax amnesties and shields; b) increased options for fixed-term labour contracts; c) the division of the three largest trade union organisations in order to isolate the CGIL; d) the transformation of the Public Administration according to business parameters; e) a foreign economic policy based on the support of exports of Italian goods.

The demand is for an economic policy able to bring the country out of the decline publically denounced only by the CGIL and which, meanwhile, has become a widely recognised issue (Camusso, Baseotto, Nicolosi and Vanacore 2003). According to Lapadula (2003) the decline is closely linked with the Italian specialisation focused on traditional industries and based on under-sized firms, while the second Berlusconi Cabinet pointed to China as being responsible for Italy's crisis. Indeed, the solution in Lapadula's view is neither duties nor 
protectionism but a new industrial model able to participate in international trade (Lapadula, 2003).

The seriousness of the Italian situation is continually denounced by the CGIL in labour, fiscal and environmental sectors (Modica, 2003) but also in the social field (Del Fattore, 2003), and in the institutional one (Troffa, 2004).

The CGIL's critique is on the government's choice of an economic development model based on labour cost and on reducing workers' rights. There are many reasons to continue the struggle against the decline (Guzzonato, 2003), above all because the financial and real estate rents - strongly supported by the Berlusconi Cabinets - led to wage cuts and penalised investment (Modica, 2004).

The CGIL proposals to tackle the economic decline are based on high quality development, extension of labour rights and on increasing the social safety net (Rassegna Sindacale, 2004), at the same time implementing an overall re-thinking of the social model (Rocchi, 2006).

Lapadula (2004) entered the general debate with his book in which he tracks the historic and economic path of Italian development from the "miracolo economico" until the early 2000s. He believes that it is necessary to face the repositioning of the Italian productive specialisation model in order to create valueadded goods, given that the traditional Italian price competitiveness based on low wages and Lira devaluation would be impossible with the Euro. In Lapadula's analysis the main problem is not the Euro but the second Berlusconi Cabinet's economic policies, which did not deal with the structural problems of the Italian development model and led to stagnation. Indeed, that Cabinet applied a neoliberal economic recipe based on reduced taxation, increased labour precariousness, public spending cuts, and also on breaking trade union unity.

In contrast, Lapadula considers it necessary to follow a high-quality development model - in order not to be vulnerable to the international lowerquality competition - supported by: i) more investments in training, research and innovation which could lead to the growth of productivity, higher work activity rate, larger firm size and recovery of the share in international trade; ii) the completion of the liberalisation process blocked by corporative interests; iii) the safeguarding of the social model; iv) a strong role of the industrial sector and $v$ ) redirection of the largest firms to strengthen the smaller ones and vi) income policies designed to increase the real wage, raise productivity and distribute income (Lapadula, 2004). 
The Italian decline also needs to be tackled through the spread of knowledge (Saltini, 2006). In this way, it would be possible to create jobs, enhance social cohesion and support well-being at all ages. Fammoni (2006) believes that it is also fundamental to deal with unreported employment and underground economy, which are other Italian structural problems. This is strictly linked with illegality and with the dark side of the current development model which needs to be fought by the union (Cristilli, 2011).

Moreover, government policies composed of a mixture of liberalism and protectionism would increase the decline, in which the low quality of human capital blocks innovation and, in turn, the low propensity to innovate prevents investment in training and research (Dacrema, 2008).

Indeed, the lack of growth is attributable to the economic thought that inspired the wrong economic policies implemented for many years and that did not solve the structural problems of the Italian economic decline (Beschi and Sanna, 2012).

The CGIL has always made its own ideas on the reforms needed for the country. In its national congress in 2006 it proposed a new kind of relationship between government and social partners, a different model of development, an innovative economic policy to avoid the so-called "politica dei due tempi" (CGIL, 2006), which means first rebalancing and then economic growth. In the following national congress in 2010 the CGIL - daily criticised by the fourth Berlusconi Cabinet (2008-2011) - called for the return to employer-union dialogue and launched several proposals on economic policies that were never taken into account (CGIL, 2010).

In order to concentrate all the proposals in a strong document, the CGIL drafted its "Program for Jobs" during its national conference held in Rome on 25th and 26th of January 2013, on the eve of the 2013 general elections.

The Program for Jobs - to which different scholars contributed - aims to place the problem of "jobs" and "demand" at the centre of the political dispute. The CGIL believes that it is not possible to have a period of new growth and development without job creation, as it is the only thing that can address the deficiencies of Italian demand and structural weakness (Sanna, 2014).

The serious geographical and intergenerational imbalances, the contraction of employment, the increased inequalities and unemployment affecting the Italian economy were analysed by the CGIL in a Keynesian perspective (lack of aggregate 
demand, the need to re-establish state intervention in the economy, and full employment as the main goal) and some Schumpeterian aspects such as the constant call for innovation (Sateriale, 2013; Sanna, 2014).

Table 1. The economic and social impact of Program for Jobs

\begin{tabular}{|c|c|c|c|c|c|c|}
\hline & \multicolumn{3}{|c|}{ Basic Scenario } & \multicolumn{3}{|c|}{ Impact of the Program for Jobs } \\
\hline & 2013 & 2014 & 2015 & 2013 & 2014 & 2015 \\
\hline Gross Domestic Product & -0.5 & 0.7 & 1 & 2.2 & 0.8 & 0.1 \\
\hline Imports & 1.7 & 4.5 & 4.8 & 6.4 & 0.2 & 1.3 \\
\hline Households Consumption & -1 & 0.6 & 0.5 & 1.4 & 0.3 & 0.5 \\
\hline Gross Fixed Investments & -1.5 & 1.4 & 2.8 & 6.7 & 2.5 & 1.1 \\
\hline Exports & 3.2 & 4 & 4.6 & 1.4 & 0.4 & 0 \\
\hline Inflation & 2.4 & 2.1 & 2.2 & -0.3 & -0.3 & -0.3 \\
\hline $\begin{array}{l}\text { Unit Labour Cost (ULC) of } \\
\text { the Private Sector }\end{array}$ & 1.8 & 1.3 & 1.7 & -2 & -0.2 & 0.3 \\
\hline Employment & -0.4 & 0.5 & 1 & 1.9 & 0.6 & 0.4 \\
\hline Unemployment Rate & 11.3 & 10.8 & 9.7 & 9.6 & 8.5 & 7 \\
\hline Real Available Income & -0.8 & -0.2 & 0.3 & 2.4 & 0.3 & 0.7 \\
\hline Public Debt (\% of GDP) & 127.3 & 125.5 & 122.8 & 126.7 & 125.9 & 124.8 \\
\hline
\end{tabular}

Source: Program tor Jobs (CGIL, 2013)

The Program for Jobs, which starts by examining the shrinking aggregate demand and aims to achieve full employment, contains several proposals in different fields: from labour policies to fiscal ones, from the Welfare State to public investments (Sanna, 2013; CGIL, 2013). The CGIL harshly criticises the neoliberal agenda implemented in Italy over the past decades through "structural reforms" because they have been completely oriented to the supply side and to cost competition, making work appear irrelevant.

The result of the general election and the formation of the Letta Cabinet (2013-2014) based on a 'great coalition' made the implementation of the Program for Jobs impossible. It nevertheless remains a detailed plan deserving attention in view of the economic thought that inspired it, the concrete proposals drafted, the indication of where the necessary resources could be found, and the potential for positive impact on the Italian economy.

Indeed, there was also an econometric study made by CER on the Program for Jobs that brought to light how the impact of the measures envisaged by CGIL represent a strong impetus to anti-cyclical policies and, in particular, showed that only direct public intervention would reduce the debt with a simultaneous improvement of GDP growth in the three years considered (2013-2015). 


\section{Concluding remarks}

This paper dealt with the so-called Italian economic decline and the CGIL's interpretation of it. In particular, it has been stressed that: i) the CGIL maintained that the Italian crisis and the increase of unemployment in the period under consideration (2003-2013) is imputed to the reduction of public spending and the measures of labour flexibility; ii) the Italian crisis has been amplified by the massive decrease of public investment. It has been shown that the theoretical basis of the CGIL's interpretation (as well as its policy prescriptions) is Post Keynesian in essence. The CGIL's interpretation is based on a supply-side Keynesism, where expansionary fiscal policy is devoted to increase both domestic demand (in a shortrun perspective) and the productivity growth (in a long-run perspective). This reconstruction has been based on documents produced by the CGIL in Rassegna Sindacale, its weekly publications, and in the Program for Jobs launched in 2013.

\section{References}

Accornero, A. (1992). La parabola del sindacato: ascesa e declino di una cultura. Bologna: Il Mulino.

Altieri, G. (2009). Un mercato del lavoro atipico: Storia ed effetti della flessibilità in Italia. Roma: Ediesse.

Altieri, G. (2010). L'esercito dei nuovi disoccupati. Rassegna Sindacale, Supplemento Economia, 8, p. 17.

AMECO (2018), Annual macro-economic database of the European Commission. Retrieved from https://ec.europa.eu/economy_finance/ameco/user/serie/ SelectSerie.cfm

Arrighi, G. (2007). Adam Smith in Beijing: Lineages of Twenty-First Century. New York: Verso.

Baccaro, L. \& Pulignano, V. (2015). Employment relations in Italy. In G. Bamber, R. Lansbury, N. Wailes \& C. F. Wright (Eds.), International and Comparative Employment Relations. National regulation, global changes (6th ed.). Sydney: Allen \& Unwin.

Bellofiore, R. (2001). I lunghi anni Settanta. Crisi sociale e integrazione economica internazionale. In L. Baldissara (Ed.), Le radici della crisi. L'Italia tra gli anni Sessanta e Settanta (pp. 57-87). Roma: Carocci. 
Bernaciak, M., Gumbell-McCormic, R., \& Hyman, R. (2015, May). El sindicalismo europeo: ¿de la crisis a la renovación? Cuadernos Fundación 1 de Mayo, 40,1-89.

Beschi, M., \& Sanna, R. (2012). Una sterile austerità. Rassegna Sindacale, 46, p. 2.

Blanchard, O., \& Giavazzi, F. (2003). Macroeconomic Effects of Regulation and Deregulation in Goods and Labor Markets. The Quarterly Journal of Economics, 118(3), 879-907. https://doi.org/10.1162/00335530360698450

Camusso, S., Baseotto, N., Nicolosi, N., \& Vanacore, G. (2003). Quella strana concezione dell'unità della Cgil. Rassegna Sindacale, 28, p. 4.

Carra, A. (2010). La non occupazione. Rassegna Sindacale, Supplemento Economia, 8, p. 23.

Carra, A. (2012). Non tutti i disoccupati rientrano nelle statistiche. Rassegna Sindacale, 43, pp. 4-5.

CGIL. (2006). Riprogettare il Paese - Lavoro, Saperi, Diritti, Libertà. In $X V$ Congresso Nazionale, Rimini, Italia.

CGIL. (2010). I diritti e il lavoro oltre la crisi. In XVI Congresso Nazionale. Rimini, Italia.

CGIL. (2013). Piano del Lavoro - Creare lavoro per dare futuro e sviluppo al Paese. In Conferenza di Programma. Roma, Italia.

Cingano, F., Torrini, R. \& Viviano, E. (2010). Il mercato del lavoro italiano durante la crisi, Questioni di Economia e Finanza (Occasional papers), no. 68, Roma: Banca d'Italia

Cristilli, C. (2011). Tutti i guasti del modello Penelope. Rassegna Sindacale, 12, p. 13.

Del Fattore, S. (2003). Alla fine la carità dello Stato. Rassegna Sindacale, 31, pp. 12.

Dota, F. (2010). Quel mercato del lavoro bloccato. Rassegna Sindacale, Supplemento Economia, 5, p. 18.

Epifani, G. (2002). E l'Italia scende in piazza per l'Italia. Rassegna Sindacale, 38, pp. 1-2.

Fammoni, F. (2006). Parte la campagna "Il rosso contro il nero." Rassegna Sindacale, 17 , pp. 1-2. 
Felettingh, A., \& Federico, S. (2011). Measuring the price elasticity import demand in the destination of Italian exports. Revista Di Economia e Politica Industriale, 38(1), 127-162. Retrieved from https://ideas.repec.org/a/fan/polipo/vhtml10.3280-poli2011-011005.html

Ferrari, M. (2016). Export Italia, Che fatica tenere il passo. Retrieved from https://www.prometeia.it/atlante/export-italia

Ferrucci, G. (2012). Gli effetti della crisi sul lavoro in Italia. Rome. Retrieved from https://www.fondazionedivittorio.it/sites/default/files/contentattachment/

Gli effetti della crisi sul lavoro in Italia -_0.pdf

Ferrucci, G. (2013). Gli effetti della crisi sul lavoro in Italia. Rome. Retrieved from https://www.fondazionedivittorio.it/sites/default/files/contentattachment/Sofferenza\%26Disagio_maggio2013_0.pdf

Fine, B. (2013). Financialization from a Marxist Perspective. International Journal of Political Economy, 42(4), 47-66. doi:10.2753/IJP0891-1916420403

Forges Davanzati, G. (2016). Credit supply, credit demand and unemployment in the mode of Augusto Graziani. Review of Keynesian Economics, 4(3), 264278. https://doi.org/10.4337/roke.2016.03.03

Forges Davanzati, G. \& Giangrande, N. (2017). Le politiche del lavoro e formative in Italia (2008-2015): un'analisi critica. In A. Di Maio \& U. Marani (Eds.), Politiche economiche e crisi internazionale. Uno sguardo sull'Europa (pp. 173-211). July.

Forges Davanzati, G., Pacella, A., \& Salento, A. (2019). Financialisation in context: the case of Italy. Cambridge Journal of Economics, 43(4), 917-936. https://doi.org/10.1093/cje/bez019

Forges Davanzati, G. \& Giangrande, N. (2019). Labour market deregulation, taxation and labour productivity in a Marxian-Kaldorian perspective: the case of Italy, Cambridge Journal of Economics, https://doi.org/10.1093/cje/bez041

Giangrande, N. (2016). As posições, as propostas e as ações da CGIL para combater o desemprego na Itália (2004-2013). Unicamp, Campinas (SP). Retrieved from http://www.repositorio.unicamp.br/handle/REPOSIP/304743

Gollin, D. (2002). Getting Income Shares Right. Journal of Political Economy, 110(2), 458-74. doi: 10.1086/338747. 
Graziani, A. (2000). L'economia italiana dal '45 alla moneta unica. Bologna: Il Mulino.

Graziani, A. (2003). The monetary theory of production. Cambridge: Cambridge University Press. doi: 10.1017/CBO9780511493546

Guzzonato, M. (2003). Dieci milioni di ragioni per andare avanti. Rassegna Sindacale, 40, pp. 1-2.

Hein, E., \& Van Treeck, T. (2010). Financialisation and Rising Shareholder Power in Kaleckian/Post-Kaleckian Models of Distribution and Growth. Review of Political Economy, 22(2), 205-233. doi: 10.1080/09538251003665628

ILO (2018). International Labour Organisation Statistics. Retrieved from https://www.ilo.org/ilostat/

ISTAT. (2011). La disoccupazione tra passato e presente. (R. Giampiero \& T. Mauro, Eds.), Argomenti (1st ed.). Rome: Sistema statistico Nazionale, Istituto Nazionale di Statistica. Retrieved from $<$ https://ebiblio.istat.it/SebinaOpac/resource/la-disoccupazionetrapassato-e-presente/IST0057459? tabDoc=tabcata>

ISTAT. (2014). Annual report. Rome. Retrieved from https://www.istat.it/it/files//2014/06/Sintesi-rapp-ann-2014-en1.pdf

ISTAT. (2015). Annual report. Rome. Retrieved from https://www.istat.it/it/files//2015/07/Sintesi-RA2015_En_Def.pdf

ISTAT. (2018). Data warehouse. Rome: Italian National Institute of Statistics. Retrieved from http://dati.istat.it/

Kaldor, N., Thirlwall, A., \& Targetti, F. (1989). Further essays on economic theory and policy. London: Duckworth.

Kalecki, M. (1943). Political Aspects of Full Employment1. The Political Quarterly, 14(4), 322-330. https://doi.org/10.1111/j.1467-923X.1943.tb01016.x

Lampa, R., \& Perri, S. (2014). Il declino e la crisi dell'economia italiana: dalla teoria ai fatti stilizzati. In R. Cerqueti (Ed.), Polymorphic Crisis. Readings on the Great Recession of the 21st century (1st ed., pp. 149-222). Macerata: Eum. Retrieved from https://pdfs.semanticscholar.org/bb4b/ 7687bd70dfb40c09b90d46dfa75ec69d6bae.pdf

Lapadula, B. (2003). Un documento vuoto. Rassegna Sindacale, 30, p. 3.

Lapadula, B. (2004). La scossa. Un patto tra produttori per la ripresa. Roma: Ediesse. 
Layard, R., Nickell, S., \& Jackman, R. (2005). Unemployment: Macroeconomic Performance and the Labour Market. Oxford: Oxford University Press. https://doi.org/10.1093/acprof:oso/9780199279166.001.0001

Leonardi, S. (2009). La flexicurity italiana: la fallita riforma degli ammortizzatori sociali. In G. Altieri (Ed.), Un mercato del lavoro atipico (1st ed., pp. 291322). Roma: Ediesse.

Modica, A. (2003). Quando l'illegalità diventa metodo. Rassegna Sindacale, 34, pp. $1-2$.

Modica, A. (2004). Contro la rendita. Rassegna Sindacale, 23, p. 9.

Moro, D. (2015). Globalizzazione e decadenza industriale. L'Italia tra delocalizzazioni, "crisi secolare» ed euro. Reggio Emilia: Imprimatur

OECD (2018), OECD Statistics, National accounts at a glance. Retrieved from https://stats.oecd.org

Pacella, A. (2009). The effects of employment insecurity on demand, productivity and employment levels. Review of Political Economy, 21(2), 273-289. https://doi.org/10.1080/09538250902834061

Pepe, A., Iuso, P., \& Loreto F. (2003). La Cgil e il Novecento italiano. Un secolo di lotte, di passioni, di proposte per $i$ diritti e la dignità del lavoro. Roma: Ediesse

Pini, P. (2013). What Europe needs to be European. Economia Politica, 30(1), 3-12. https://doi.org/10.1428/73097

Ramskogler, P. (2007). Uncertainty, market power and credit rationing (Department of Economics Working Paper Series No. 105). Vienna. Retrieved from http://epub.wu.ac.at/312/1/document.pdf

Rassegna Sindacale (2004), Art. 18: premiata la coerenza della CGIL, 39, p. 2

Reyneri, E. (1995). Italia, lunga attesa al riparo della famiglia e delle garanzie pubbliche. In O. Benoît-Guilbot, D. Gallie, \& L. Bruzzese (Eds.), La disoccupazione di lunga durata. Napoli: Liguori.

Rocchi, N. (2006). Il vizio antico del protezionismo. Rassegna Sindacale, 12, p. 6.

Saltini, L. (2006). Se non sai non sei: avviata la campagna di sensibilizzazione contro l'analfabetismo di ritorno. Rassegna Sindacale, 22, p. 8. 
Sanna, R. (2013). L'economia pubblica per il Piano del Lavoro: l'impatto macroeconomico di una nuova regolazione di nuovi investimenti pubblici e di un intervento pubblico diretto alla creazione di nuova occupazione. In L. Pennacchi (Ed.), Tra crisi e grande trasformazione: Libro bianco per il Piano del Lavoro 2013 (Collana Sa). Roma: Ediesse.

Sanna, R. (2014). L'occasione da non perdere. In V. Comito, N. Paci, \& G. Travaglini (Eds.), Un paese in bilico: L'Italia tra crisi del lavoro e vincoli dell'euro. Rome: Ediesse.

Sateriale, G. (2013). Un'impostazione dal basso. Rassegna Sindacale, 3, p. 4.

Troffa, M. (2004). Il disegno di un'altra Italia autoritaria e plebiscitaria. Rassegna Sindacale, 21, p. 4.

Visser, J. (2015). ICTWSS Data base. version 5.0. Amsterdam Institute for Advanced Labour Studies AIAS. Amsterdam. Retrieved from www.uvaaias.net/208 